\title{
Christian involvement in Sustainable Development Goals
}

\author{
Raymond Downing ${ }^{a}$ \\ ${ }^{a}$ MD, Senior Lecturer, Department of Family Medicine, Moi University School of Medicine, Kenya
}

\section{Introduction}

The Sustainable Development Goals (SDGs) describe the world we all want: no poverty, zero hunger, good health for all, reduced inequalities, sustained economic growth, peace and justice. ${ }^{1}$ We, Christians, want these as much as anyone. These goals, however, are for the post-apocalyptic world, the world after the return of Christ. The distinction is important. The world we long for, where there is no mourning or crying or pain or death, will come, but only after the fall of Babylon who bragged that she would never be in mourning. ${ }^{2,3}$ It was a reasonable brag, in light of the considerable political and economic power of Babylon - of all Babylons. ${ }^{4}$ The kings and merchants of today's Babylons have enough excess wealth to be able to imagine a world with no poverty or hunger or inequality, to even set sustainable goals to achieve those ends.

But the Biblical narrative does not see Babylon and its kings and merchants as achieving zero hunger and good health for all and an absence of the mourning that goes with death and disease. It sees rather the collapse of Babylon. Nevertheless, the Bible is quite clear about hunger and poverty and peace and justice. From leaving the gleanings of the field for the poor and sojourner in Leviticus 19, through the multiple injunctions in Psalms and Proverbs about concern for the poor and Isaiah's blunt "seek justice, correct oppression, defend the fatherless, plead for the widow," to Jesus' spelling out what he had been doing, "the blind receive their sight, the lame walk, lepers are cleansed, and the deaf hear . . .," and James' exposure of the injustice of "the wages of the laborers who mowed your fields, which you have kept back by fraud," the Biblical ideal looks a lot like the world of the Sustainable Development Goals. ${ }^{5,67,8,9}$

Consequently, the Christian Journal for Global Health has called for papers to explore Christian involvement in SDGs. Recognizing that in the new SDGs "there is very little specifically related to healthcare," the Journal notes that the SDGs "express a more sophisticated recognition of the complexities of determinants of human health" including social determinants of health. "The public sector is increasingly recognizing the key role of religious health assets in sustaining progress in development. . . . In order to retain credibility for this work and message, Christians are called to use contextual language, to measure, evaluate, and report outcomes. . . " 10 This paper seeks to examine the involvement of Christians with the SDGs.

Certainly, if someone's faith and institutional religious affiliation helps to improve the health of people, that it is, in fact, a social determinant of health, that is useful. But why are we as Christians interested in the "the key role of religious health assets in sustaining progress in development," which "the public sector is increasingly recognizing?"10 "Religious health assets" are clearly sociological qualities, part of the social determinants of health. Any religion offers this; there is nothing distinctly Christian about it. Christians should be free to offer their religious health assets - recognizing that this is no more distinctively Christian than, say, a Christian surgeon performing technically good surgery.

The key role of Christianity cannot just be a piece of a development goal, a quality to make that goal more attainable, to make more people 
healthy. Our faith is not subject to measurement; we were not left on earth as Christians to help accomplish some global development goal. Why should we want "to retain credibility for this work and message?"10 Are we trying to gain the praise and respect of the world or fit in with their agenda? Our first task as Christians should be to critique the development goals themselves and the means of arriving at them.

What is this development that is now so assumed that we can remove the word "development" from Sustainable Development Goals and simply call them "Global Goals?"11 The appearance of this development coincided with the conclusion of WWII and the ending of the colonial period. ${ }^{12}$ The "developed" world, the rich countries which had just nearly destroyed each other for the second time in one generation, decided that the rest of the world needed developing. For the next half a century they debated the nature of this development, a debate that took place in the context of the new Cold War. The Soviet Union and its allies believed that development would come about through central government planning, employing socialist or communist principles. The West believed that the capitalist market alone was sufficient for development. Yet, note that for both sides there was a fundamental agreement on two points: 1) the rest of the world, the "Third World," needed "development," and 2) the key to development was economic: development meant economic development. All other aspects of national interest, culture, history, environment, and religion, were secondary.

However, with the collapse of the Soviet Union, there is no longer a debate on how to arrive at this economic development. "Development" now has only one meaning and one method: free markets. And in order for market economies to function, they must grow. Yet by the 1970s, it was very clear that the earth and its people could not withstand unlimited industrial growth, which was tied to unlimited economic growth. Books with titles like Limits to Growth and Small is Beautiful appeared; their titles speak for themselves. The development discussion was maturing, and Christian thinkers were at the core of this discussion. In 1964, Jacques Ellul's The Technological Society appeared in English. ${ }^{13}$ Here he made clear that despite economic differences between East and West, both were committed to technology as the means of "progress." Unfortunately, there are no built-in negative feed-back mechanisms to the growth of technology. We have an imposed "technological imperative:" what can be done will be done, and we call that "progress."

Building on the same Christian understanding, Ivan Illich, in 1980, defined "development" as "the transformation of subsistence-oriented cultures and their integration into the economic system." ${ }^{\prime 4} \mathrm{He}$ was clear about the implications of this definition: "This expansion proceeds at the cost of all other traditional forms of exchange." 15 Illich made clear what was by now becoming obvious, that third world development was only economic development, a development that progressively erased indigenous cultures.

Then, in 1989, when the communist vs capitalist debate began to evaporate with the fall of the Berlin Wall, the nature of the economic system into which all subsistence-oriented cultures were integrated was no longer debatable. The only system left was the Market. The market, as we noted above, works by growing. Today, everything is growing, straining the ability of the earth to sustain that growth, and that growth increasingly benefits the very few. Five years ago, half of the world's wealth was controlled by 388 people. Today the number that controls half the world's wealth has shrunk to only $62 .{ }^{16}$

So, how is this related to Christian participation in the SDGs? The CJGH rightly saw that the underlying purpose of the SDGs is "human flourishing," a bleak prospect when wealth is being increasingly concentrated rather than distributed. But, perhaps it is not so important that we as Christians embrace the SDGs. Our ultimate task is love, which cannot usually be measured as statistical change. Of 
course we can choose to work in projects that build systems and measure their output as data, if that is our occupation. But as Christians that is not the same as our vocation, our calling. When we love, statistics may not improve. And if statistics do improve as a result of our work, we can rejoice but should not be complacent in thinking that that is the only improvement needed in the world. We still live in Babylon.

SDGs are short and medium term goals; they, and the measurement of them, are means to an end. Jacques Ellul frequently pointed out that in technological societies; all of our activities have become means. We are so focused on techniques that we neglect true ends; our technological means have become our ends. ${ }^{17}$ There is nothing wrong with measurable goals - which may be means to some greater end (such as human flourishing or human redemption) - except when those means become the ends in themselves; and they can easily become ends because we can control means far better than ends. We can understand and engage with means, precisely because they are specific and measurable and achievable and all the rest. If we, as Christians, fully embrace SDGs, we must never forget that SDGs are only means. If we forget, the SDGs will be just as cruel a joke as Alma Ata's "Health for All by the Year 2000.”

\section{References}

1. United Nations Development Programme. [Internet]. A New Sustainable Development Agenda [accessed 9 May, 2016]. Available from: http://www.undp.org/content/undp/en/home/mdgov erview.html

2. Revelation 21:1-4

3. Revelation 18:7

4. Revelation 18: 9, 11.

5. Leviticus 19:10

6. For example, Psalm 9:12, 41:1, 68:10, 72:2ff, 82:3-4, 112:9, 113:7. 132:15, Proverbs 14:21,31, 19:17, 22:9, 28:29, 31:9.

\section{Isaiah $1: 17$}

8. Luke 7:22

9. James 5:4

10. Christian Journal for Global Health (Internet). Announcements [accessed 9 May, 2016]. Available from

http://journal.cjgh.org/index.php/cjgh/announceme $\underline{n t}$

11. "The 2030 Agenda comprises 17 new Sustainable Development Goals (SDGs), or Global Goals, which will guide policy and funding for the next 15 years, beginning with a historic pledge to end poverty. Everywhere. Permanently." United Nations Development Programme [Internet]. A New Sustainable Development Agenda [cited 9 May, 2016]. Available from:

http://www.undp.org/content/undp/en/home/mdgov erview.html

12. This brief discussion is drawn from the arguments fully developed. In Sachs W, editor. The development dictionary, $2^{\text {nd }}$ ed. London: Zed

Books; 2009. Available at

https://www.google.com/search?client=ubuntu\&ch annel=fs \&q=Sachs+The+Development+Dictionary $\underline{\text { \&ie }=\text { utf- } 8 \& \text { oe }=\text { utf- } 8}$

13. Ellul, J, The technological society. New York: Vintage Books; 1964.

14. "The condition at the end of time which today takes its form in our thoughts, feelings, and perceptions - can only be grasped by those who unequivocally believe in the reality of the Gospel." Duden, B, quoting Illich in "Ivan Illich. Beyond Medical Nemesis (1976): The Search for Modernity's Disembodiment of "I" and "You", available at www.pudel.uni-

bremen.de/pdf/Iv tra_b.pdf. "I could not have analyzed medicine without bringing into this analysis my passionate attempt to understand a little bit of the Gospels. . " Illich, in Cayley D, editor. The rivers north of the future. Toronto: Anansi Press; 2005. p 121.

15. Illich, I, In the mirror of the past. London: Marion Boyars Publishers; 1992, p. 21-2. 
16. Yahoo! News [Internet]. Keneally M. Richest 62 people control same wealth as poorest half of world's population, report states [19 January,

2016]. Available from

http://news.yahoo.com/richest-62-people-control- same-wealth-poorest-half-165238838--abc-newstopstories.html

17.Jacques E. The presence of the kingdom. New York: Seabury Press; 1967. [Chapter III “The Ends and the Means"]

Peer Reviewed.

Competing Interests: None declared.

Correspondence: Raymond Downing, Moi University School of Medicine, Kenya.armdown2001@yahoo.com

Cite this article as: Downing R. Christian involvement in Sustainable Development Goals. Christian Journal for Global Health (May 2016), 3(1):73-76.

CDowning R This is an open-access article distributed under the terms of the Creative Commons Attribution License, which permits unrestricted use, distribution, and reproduction in any medium, provided the original author and source are properly cited. To view a copy of the license, visithttp://creativecommons.org/licenses/by/3.0/

www.cjgh.org 